\title{
PRODUKTIVITAS SAPI BALI JANTAN YANG DIPELIHARA PADA LAHAN GAMBUT BASAH
}

\author{
(Productivity of Male Bali Cattle Reared on Wet Peatlands)
}

\author{
Kristyan Amiano', Yemima ${ }^{2}$, Dwi Dedeh Kurnia Sari ${ }^{2}$ \\ ${ }^{1,2}$ Program Studi Peternakan, Fakultas Peternakan, Universitas Kristen Palangka Raya \\ Jl. J.P. Jandam R.TA Milono Km. 8,5 Palangka Raya,73112 \\ Penulis koresponden: kristyanamiano96@gmail.com
}

Article Submitted: 12-02-2021

Article Accepted: 20-05-2021

\begin{abstract}
This study aims to evaluate male Bali cattle as potential livestock on peatlands. This research was conducted from October 2020 to December 2020. The method used in this study was a survey in the form of direct observation and measurement of livestock to obtain primary data. The sample of the area was taken by purposive sampling based on the largest Balinese cattle population in wet peatlands, with a total of 60 male Bali cattle. The variables observed included variables, body length $(\mathrm{cm})$, shoulder height $(\mathrm{cm})$, chest circumference $(\mathrm{cm})$, body weight $(\mathrm{kg})$, forage characteristics, and seedlings based on SNI-2017 for Bali cattle. The data obtained were analyzed descriptively by calculating the average value and standard deviation. The results show that the maintenance of male Bali cattle on wet peatlands can utilize natural greenery so that it can reduce production costs. The performance of male Bali cattle production can be seen as the criteria for selecting superior male seedlings in wet peatlands, where the percentage of entering class I was $33.4 \%$ of the total population being maintained. Wet peatlands can be used as a source of Balinese cattle to meet the need for productive beef cattle.
\end{abstract}

Keywords: Bali Cattle, Vital Statistics, Selection, Wet Peatlands.

\section{PENDAHULUAN}

Sapi Bali merupakan ternak potong lokal asli Indonesia yang tersebar di berbagai daerah salah satunya penyebarannya berada pada lahan gambut Kalimantan Tengah. Sapi Bali memiliki keunggulan dan produktivitas yang baik terhadap berbagai lingkungan sehingga dikembangakan serta dimanfatakan sebagai sumber kebutuhan hewani. Keunggulan sapi Bali antara lain fertilitas dan persentase karkas tinggi serta mudah adaptasi terhadap lingkungan (Matondang dan Talib, 2015).

Lahan gambut merupakan bentangan lahan yang terbentuk dari hasil endapan tumbuhan atau bahan organik di daerah yang selalu tergenang air yang menjadikan lahan basah dan endapan yang tidak tergenang air menjadikan lahan kering (Amiano et.al, 2020). Pemeliharan sapi Bali pada lahan gambut basah di Provinsi Kalimantan Tengah merupakan pemeliharaan berbasis lahan gambut, kebutuhan pakan dan manajemen pemeliharaan ditempatkan dan disediakan oleh hijuan alam yang tumbuh dan berkembang terkhusus pada area rawarawa gambut yang tergenang.

Sumber bibit atau bakalan induk pejantan sapi Bali yang baik tentunya memiliki produktivitas yang unggul. Ternak yang unggul tentunya secara kualitatif memiliki bobot badan yang tinggi serta ukuran yang relatif besar. Faktor 
pemeliharaan yang dipengaruhi oleh kondisi lingkungan lahan gambut basah akan mempengaruhi karaktersitik induk-induk pejantan sapi Bali yang dapat ditunjukkan oleh dampak kondisi lingkungan dan manajemen pemeliharaan yang menagkibatkan perkembangan ukuranukuran tubuh meliputi panjang badan, tinggi pundak, lingkar dada serta bobot badan. Lahan gambut diharapkan dapat menjadi lumbung sumber bibit sapi Bali jantan sehingga perlu adanya kajian untuk memperoleh informansi mutu genetik sapi Bali yang dipengaruhi oleh dampak dari manajemen pemeliharaan.

\section{METODE PENELITIAN}

\section{Metode dan Waktu}

Penelitian ini menggunakan metode survei berupa pengamatan secara langsung ke lokasi penelitian. Data yang dikumpulkan data primer dan data sekunder. Data primer diperoleh dari pengamatan dan pengukuran secara langsung tehadap ternak dan data sekunder diperoleh dari Recording atau cacatan peternak. Materi penelitian meliputi sapi Bali jantan yang dipemelihara secara intensif. Jumlah sapi Bali jantan yang diamati sebanyak 60 ekor dengan umur $>18-24$ bulan. Penelitian ini telah dilaksanakan pada Oktober sampai Desember 2020 di Provinsi Kalimantan Tengah, Kabupaten Pulang Pisau, Kecamatan Jabiren Raya, Desa Tanjung Taruna.

\section{Parameter yang diamati}

Pengamatan terhadap aspek produktivitas ternak sapi Bali pada lahan gambut menggambarkan kondisi perkembangan dan pertumbuhan ternak, dengan pengukuran vital statistik ternak sapi Bali meliputi : 1). Panjang badan: dengan mengukur bokong bahu (tuberositas humeri) sampai ujung tulang duduk (tuber ischii), menggunakan tongkat ukur. 2). Tinggi Pundak: dengan mengukur jarak dari permukaan lanti yang rata sampai bagian tertinggi pundah melewati bagian (skapulla) secara lurus dengan menggunakan tongkat ukur. 3). Lingkar dada: diukur dengan melingkari pita ukur pada bagian dada dibelakang bahu. 4). Bobot badan: pengukuran bobot badan ternak dengan menggunakan pita ukur (rondo). Pengukuran bobot badan sapi melalui pengukuran lingkar dada dan panjang badan, lanjutkan dengan estimasi dengan perhitungan. 5). Penilaian bibit sapi Bali jantan berdaraskan presentase Standar Nasional Indonesia (SNI Sapi Bali-2017). 6). Nutrisi pakan diketahui dengan analisis proksimat meliputi Bahan Kering (BK), Abu, Protein Kasar (PK), Serat Kasar (SK), Lemak Kasar (SK). Analisa bahan pakan dilakukan di Laboratorium Minat Nutrisi dan Makanan Ternak Universitas Brawijaya.

\section{Analisis Data}

Data yang diperoleh dianalisis secara deskriptif dengan mengetahui nilai rata-rata dan simpangan baku, menggunakan rumus menurut (Sudjana, 2002) yaitu :

$$
\begin{aligned}
\overline{\mathrm{x}} & =\sum \frac{\mathrm{Xi}}{\mathrm{n}} \\
\mathrm{SB} & =\sqrt{\frac{\sum(X-\bar{X})^{2}}{n-1}}
\end{aligned}
$$

Keterangan :

$$
\begin{array}{ll}
\overline{\mathrm{X}} & =\text { Nilai rata-rata dari Variabel } \\
\sum \mathrm{Xi} & =\text { Jumlah semua nilai variabel } \\
\mathrm{SB} & =\text { Simpangan baku } \\
\mathrm{N} & =\text { Banyaknya pengamatan. }
\end{array}
$$

\section{HASIL DAN PEMBAHASAN}

\section{Karakteristik Hijauan Lahan Gambut Basah}

Pakan yang diberikan pada ternak sapi Bali dilahan gambut merupakan pakan dari hijauan alami lahan gambut yang tumbuh dan berkembang dihamparan genangan lahan yang basah. Jenis pakan yang tumbuh yakni rumput kumpai minyak 
dan kumpai batu. Komposisi kandungan nutrisi hijuan pakan pada lahan gambut basah dilihat pada Tabel 1 berikut.

Tabel 1. Kandungan Nutrisi Hijauan Pakan sapi Bali di Lahan Gambut Basah

\begin{tabular}{lccccc}
\hline \multirow{2}{*}{ Jenis Hijauan } & \multicolumn{5}{c}{ Kandungan Nutrisi } \\
\cline { 2 - 6 } & $\mathrm{BK}(\%)$ & $\mathrm{Abu}(\%)$ & $\mathrm{PK}^{*}(\%)$ & $\mathrm{SK}(\%)$ & $\mathrm{LK} *(\%)$ \\
\hline $\begin{array}{l}\text { Kumpai Minyak (Hymenache } \\
\text { amplexicaulis (Haes)) }\end{array}$ & 78,25 & 7,06 & 7,80 & 29,75 & 0,80 \\
$\begin{array}{l}\text { Kumpai Batu (Ischaemum } \\
\text { polystachyum. J. Presl) }\end{array}$ & 68,01 & 8,60 & 9,65 & 30,43 & 0,94 \\
\hline
\end{tabular}

Keterangan: Dianalisis di Laboratorium Minat Nutrisi dan Makanan Ternak Universitas Brawijaya, *) Berdasarkan $100 \%$ bahan kering.

Tabel 1 menunjukkan bahwa rumput alam pada lahan gambut basah memiliki kandungan protein yang tinggi dimana tumbuhan rumput kumpai minyak dan kumpai batu ini yang mampu tumbuh di area lahan gambut basah serta tidak terdapat introduksi tumbuhan lain yang hidup di hamparan rawa gambut. (Aman dan Harsita, 2019) menyatakan bahwa pakan merupakan salah satu faktor terpenting dalam pengembangan ternak. (Sari dkk., 2016) menyatakan penyediaan hijauan dari peternak masih merupakan masalah utama dikarenakan keterbatasan lahan untuk menanam khusus hijauan pakan dan umumnya akan semakin sulit didapat pada musim kemarau sehingga berdapak kekurangan pakan. Lahan gambut bisa menjadi alternatif pengembangan ternak karena lahan gambut memiliki potensi hijuan alamiah yang berlimpah baik pada musim kemarau maupun musim penghujan.
Rumput kumpai merupakan salah satu jenis rumput rawa yang berpotensi cukup baik sebagai hijauan makanan ternak dengan habitat di daerah rawa atau payau yang cerah, terbuka serta tumbuh lebih baik ditempat tergenang air dengan kedalaman air mencapai $1-2$ meter (Akhadiarto dan Fariani, 2012). Lahan gambut di Kalimantan Tengah memiliki peluang dan potensi yang tinggi sebagai sentra pertanian dan peternakan karena memiliki hijauan alam yang berlimpah (Febriani dkk., 2018). Salah satu faktor terpenting dalam menjaga kestabilan peternakan adalah tersedianya hijauan pakan yang berkualitas untuk makanan ternak agar produktivitas ternak dapat optimal. Pemanfaatan hijauan alam lahan gambut sebagai sumber pakan ternak diharapkan dapat meningkatkan sektor peternakan rakyat maupun komesil di Kalimantan Tengah.

\section{Produktivitas Sapi Bali Jantan}

Tabel 2. Perkembangan dan pertambahan ukuran sapi Bali Jantan pada lahan gambut

\begin{tabular}{|c|c|c|c|}
\hline Variabel & Nilai Terendah & Nilai Tertinggi & Rataan $\pm \mathrm{SD}$ \\
\hline Bobot Badan $(\mathrm{kg})$ & 230 & 280 & $311,5 \pm 45,14$ \\
\hline Panjang Badan (cm) & 107 & 117 & $111,4 \pm 3,47$ \\
\hline Tinggi Pundak $(\mathrm{cm})$ & 119 & 122 & $120,0 \pm 1,49$ \\
\hline Lingkar Dada $(\mathrm{cm})$ & 140 & 162 & $152,4 \pm 9,65$ \\
\hline
\end{tabular}

Tabel 2 menunjukkan bahwa pemeliharaan ternak sapi Bali jantan pada lahan gambut basah pada umur >18-24 bulan yang diberikan rumput alam kumpai 
memiliki berat badan tertinggi yakni $280 \mathrm{~kg}$, berat badan terendah $230 \mathrm{~kg}$, dengan ratarata berat badan $311,5 \pm 45,14 \mathrm{~kg}$. Panjang badan ternak terbesar $117 \mathrm{~cm}$, terendah 107 $\mathrm{cm}$ dengan rata-rata panjang badan $111,4 \pm 3,47 \mathrm{~cm}$. Tinggi pundak tertinggi 119 $\mathrm{cm}$, terendah $122 \mathrm{~cm}$ dengan rata-rata tinggi pundak 120,0 $\pm 1,49 \mathrm{~cm}$. Lingkar dada ternak terbesar $162 \mathrm{~cm}$, terendah $140 \mathrm{~cm}$ dengan rata-rata lingkar dada $152,4 \pm 9,65 \mathrm{~cm}$. Kondisi tubuh ternak sapi Bali jantan memperlihatkan bahwa indikasi penyimpanan cadangan energi yang dapat mempengaruhi pertumbuhan dan perkembangan dan dapat dinilai sebagai kreteria seleksi sapi Bali jantan yang unggul. Pemerintah meiliki ketentuan Standar Nasional Indinesia untuk indikasi panjang badan, tinggi badan (tinggi pundak atau tinggi gumba) dan lingkar dada sebagai ukuran statistik vital yang dijadikan sebagai kriteria pemilihan bibit sapi potong di Indonesia. Ukuran statistik vital untuk calon pejantan sapi Bali umur 18 sampai 24 bulan ditetapkan yakni panjang badan $110 \mathrm{~cm}$, tinggi badan $120 \mathrm{~cm}$, dan lingkar dada 147 cm (SNI sapi Bali, 2017). Ukuran statistik vital yang ditetapkan pemerintah ini dibandingkan dengan ukuran statistik vital yang ditemukan pada penelitian ini, maka dapat terlihat bahwa calon-calon pejantan sapi Bali umur 18 sampai 24 bulan di wilayah penelitian masih berada di pertengahan standar ukuran statistik vital yang ditetapkan pemerintah, sehingga pemeliharaan perlu ditingkatkan lagi dan menjaga kemungkinan penurunan mutu genetik yang disebabkan oleh faktor lingkungan dan manajemen pemeliharaan. Barahum et.al., (2017) menyatakan bahwa performans seekor ternak merupakan hasil dari pengaruh komulatif dari faktor lingkungan yang dialami oeleh ternak tersebut serta dipengaruhi juga oleh faktor genetik. Takandjandji (2015) menyatakan bahwa ukuran-ukuran tubuh dan bobot badan berkembang sejalan dengan bertambahnya umur dan dipengaruhi oleh faktor pengelolaan terutama pakan dan kesehatan ternak. Faktor pakan sangat mempengaruhi perkembangan kondisi bobot badan ternak yang dipelihara, pada saat terjadi kekurangan pakan ternak mengakibatkan penurunan berat badan, khususnya disebabkan oleh kehilangan lemak badan dan dengan perbaikan pakan mempengaruhi perkembangan atau perbaikan kondisi badannya akan lebih cepat pulih kembali (Wijono dkk., 2001).

\section{Performans Sapi Bali Jantan Pada lahan Gambut Basah}

Tabel 3. Performans bibit sapi Bali jantan pada lahan gambut basah masuk SNI-2017

\begin{tabular}{|c|c|c|c|}
\hline \multirow{2}{*}{ Bulan (Umur) } & \multirow{2}{*}{ Kelas } & \multicolumn{2}{|c|}{ Lahan Gambut Basah } \\
\hline & & Jumlah & Presentase \% \\
\hline \multirow{4}{*}{$>18-24$} & I & 20 & 33,4 \\
\hline & II & 12 & 20,0 \\
\hline & III & 14 & 23,3 \\
\hline & TMK & 14 & 23,3 \\
\hline
\end{tabular}

Keterangan: TMK = Tidak Masuk Kelas.

Tabel 3 menunjukkan bahwa sapi Bali jantan pada lahan gambut basah umur 18-24 bulan sudah masuk kreteria Standar Nasional Indonesia-2017 sebagai bibit dengan presentase kelas I yakni $33,4 \%$ dan kelas II yakni $20,0 \%$, pada kelas III sebesar
23,3\% sama jumlahnya dengan ternak yang tidak masuk seleksi bibit. Lahan gambut basah dapat dijadikan sumber bibit sapi Bali untuk memenuhi kebutuhan akan ternak potong yang produktif. Berdasarkan kriteria beberapa keunggulan yang dimiliki sapi Bali 
maka layak ditingkatkan dan dikembangkan baik dari segi mutu genetik maupun populasinya. Barahum et.al.,(2017), menyatakan bahwa performa seekor ternak merupakan hasil dari pengaruh faktor genetik dan pengaruh komulatif dari faktor lingkungan yang dialami oleh ternak tersebut. Nugraha et.al.,(2015) menyatakan bahwa umur ternak mempengaruhi kondisi statistik vital dan bobot badan menyatakan bahwa.Ternak yang dipelihara pada lahan gambut yang berbeda antara lahan gambut basah dan kering juga mempengaruhi perbedaan performans ukuran vital statistik lingkar dada sapi Bali. Bibit sapi Bali yang berkualitas perlu pilih pada suatu populasi sehingga didapat kualitas yang unggul dan dapat dikembangkan untuk generasi penerus dari populasi ternak yang ada. Menurut Oka (2010) menyatakan bahwa seleksi merupakan salah satu tindakan yang dapat dilakukan untuk meningkatkan mutu genetik ternak.

\section{KESIMPULAN}

Pemeliharaan sapi Bali jantan pada lahan gambut basah dapat memanfatakan hijaun pakan alami sehingga dapat menurunkan biaya produksi. Performans produksi sapi Bali jantan dapat dilihat sebagai kreteria seleksi bibit pejantan unggul pada lahan gambut basah terdapat presentase masuk kelas I dengan jumlah 33,4 \% dari total populasi yang dipelihara. Lahan gambut basah dapat dijadikan sumber bibit sapi Bali untuk memenuhi kebutuhan akan ternak potong yang produktif.

\section{UCAPAN TERIMA KASIH}

Penulis mengucapkan terima kasih kepada Lembaga Penelitian dan Pengabdian Masyarakat Univeritas Kristen Palangka Raya yang telah mendanai penelitian ini dan dukungan dari Dekan Fakultas Peternakan Univeritas Kristen Palangkaraya.

\section{DAFTAR PUSTAKA}

Akhadiarto, S., \& A. Fariani. (2012). Evaluasi Kecernaan Rumput Kumpai Minyak(Hymenachne amplexicaulis) Amoniasi Secara In Vitro. Jurnal Sains dan Teknologi Indonesia, 14(1): 50-55.

Amam \& P. A. Harsita. (2019). Tiga Pilar Usaha Ternak : Breeding, Feeding, and Management. Jurnal Sain Peternakan Indonesia, 14(4): 431-439.

Amiano, K., W. Busono., \& S. Maylinda. (2020). Productivity of Bali Cattle on Peatland in Central Kalimantan. Journal of Tropical Animal Production, 21(1): 39-43.

Barahum, A., H. L. L. Belli, \& T.M. Hine. (2017). Karaktersitik pejantan Muda sapi Bali pada Peternakan Rakyat di Desa Merabu Kabupaten Kupang. Jurnal Peternakan Nusantara, 3(1): 11-16.

Febriani, W., B. S. Anggoro, R. Komala \& S. Agustina. (2018). Explorasi dan Identifikasi Hijauan Potensial Di Lahan Gambut Kotawaringin Barat Kalimantan Tengah. BIOSFER Jurnal Tadris Pendidikan Biologi, 9(1): 100113.

Matondang, R, H. \& C. Talib. (2015). Model Pengembangan Sapi Bali dalam Usaha Integrasi di Perkebunan Kelapa Sawit. Wartazoa, 25(3): 147-157.

Oka, I G. L. (2010). Conservation and genetics improvement of bali cattle. Proceeding International Seminar on "Conservation and Improvement of World Indigenous Cattle". 3-4 September 2010. Held by Studi Center for Bali Cattle Udayana University. Bali. Indonesia. 
Sari, A., Liman. \& Muhtarudin. (2016). Potensi Daya Dukung Limbah Tanaman Palawija Sebagai Pakan Ternak Ruminansia Di Kabupaten Pringsewu. Jurnal Ilmiah Peternakan Terpadu,4(2): 100-107.

Standar Nasional Indonesia. (2017). Bibit sapi potong-bagian 4. SNI 751-4.2017. Retrieved from http://bibit.ditjenpkh.pertanian.go.id/si tes/deafult/files/SNI 207651.4-2017 Bibit sapi potong Bagian 4 Bali.pdf.

Sudjana. 2002. Metode Statistka. Edisi keenam. Banding : Tarsito.
Takandjandji, M. \& R. Sawitri. (2015). Ukuran Morfometrik Banteng (Bos javanicus) untuk Menduga Bobot Badan. Jurnal Hutan dan Konservasi Alam, 12(1): 59-73.

Wijono, B. D., Aryogi, \& A. Rasyid. (2001). Pengaruh Berat Badan Awal Terhadap Pencapaian Hasil Pada Penggemukkan Sapi Potong di Peternakan Rakyat. Pusat Penelitian dan Pengembangan Peternakan.Balai Penelitian dan Pengembangan. Pertanian, Bogor.
Departemen 